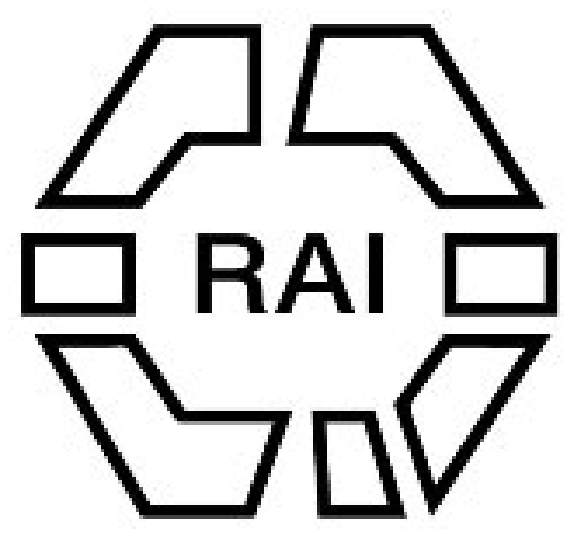

Notes on the Kikuyu and Kamba Tribes of British East Africa

Author(s): H. R. Tate

Source: The Tournal of the Anthropological Institute of Great Britain and Ireland, Vol. 34

(Jan. - Jun., 1904), pp. 130-148

Published by: Royal Anthropological Institute of Great Britain and Ireland

Stable URL: http://www.jstor.org/stable/2843090

Accessed: 15/06/2014 11:09

Your use of the JSTOR archive indicates your acceptance of the Terms \& Conditions of Use, available at http://www.jstor.org/page/info/about/policies/terms.jsp

JSTOR is a not-for-profit service that helps scholars, researchers, and students discover, use, and build upon a wide range of content in a trusted digital archive. We use information technology and tools to increase productivity and facilitate new forms of scholarship. For more information about JSTOR, please contact support@jstor.org. 


\section{NOTES ON THE KIKUYU AND KAMBA TRIBES OF BRITISH EAST AFRICA.}

By H. R. TATE.

\section{[With Plates II-V.]}

\section{The Akikuyu. ${ }^{1}$}

THE following notes which I have made on the Kikuyu tribe have been collected in the Kenya Province of the East Africa Protectorate, and I propose to describe

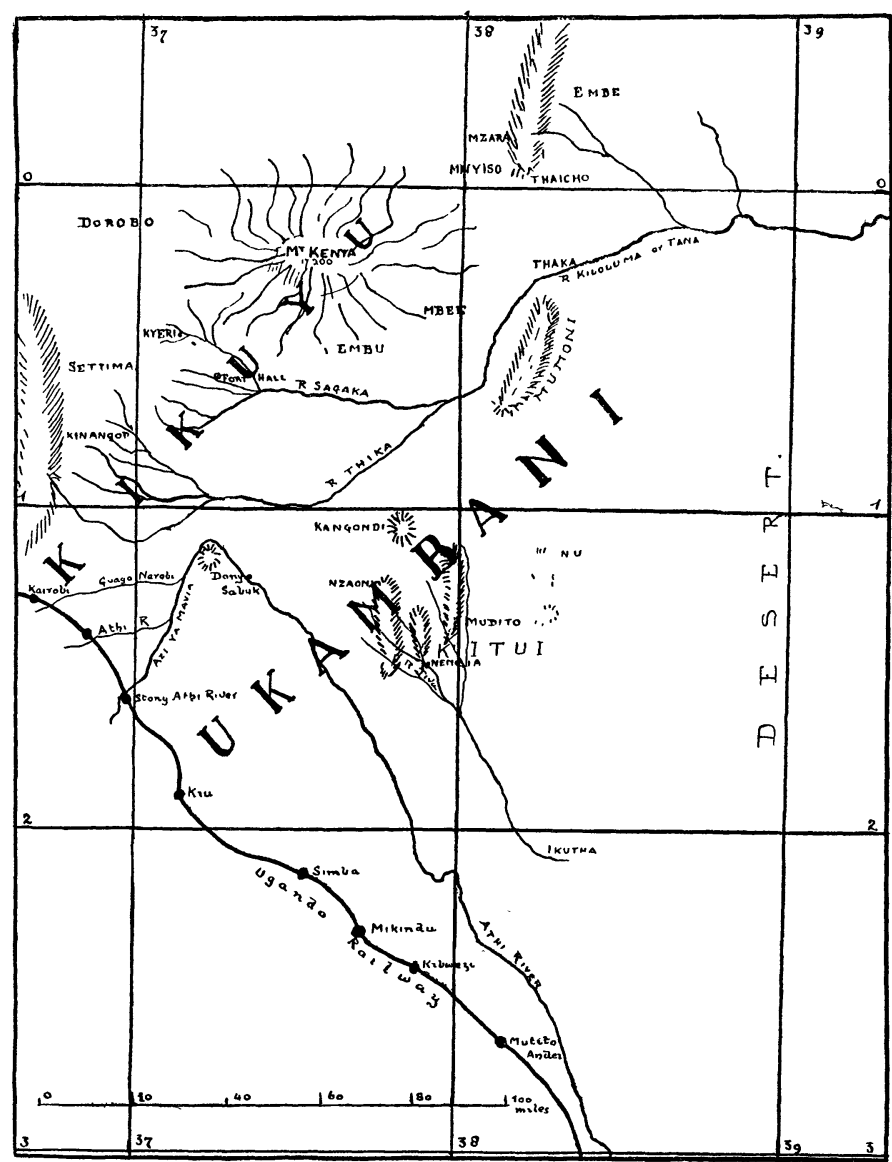

FIG. 1.-MAP SHOWING DISTRIBUTION OF KIKUYU AND UKAMBANI ; BRITISH EAST AFRICA. briefly thegeographical conditions of this part of the world before proceeding to a description of the people themselves and their mode of dress.

The Kenya Province comprises roughly all the highlands within a radius of fifty miles around Mount Kenya, and is bounded on the west by the Laikipia Escarpment, which runs as far south as Engijabi Hill, where it joins the Kikuyu Escarpment. Although the northern boundary of the Province is as yet undefined, the Kikuyu tribe is not found in any numbers north of the equator or east of longitude

$38^{\circ} \mathrm{E}$., while their southern range may be taken as bounded by the Nairobi river, which separates the Kikuyu country proper from Masailand.

1 Mukikuyu = a Kikuyu man. Akikuyu = Kikuyu people. 
In studying native life it is generally found that, to a large extent, the country in which he lives moulds the character and habits of the man. It will not be amiss, therefore, to describe the country and products of the Akikuyu and show to what extent the latter have been influenced by their surroundings and climate.

From Mount Kenya itself can be traced the extreme fertility of the Province to which it gives its name. From its snowfields and glaciers arise the numerous rivers and streams which water so abundantly the valleys and plains lying around its far-reaching spurs. Its white-capped peaks can be seen from at least one hundred miles on every side and constantly remind the traveller that, although very little south of the equator, he is also within sight of the third highest mountain in Africa, whose 17,200 feet are only surpassed by the great Kilima Njaro and the comparatively unknown Ruwenzori. The whole of the Kikuyu country is composed of highlands ; Fort Hall, the headquarters of the Kenya Province, being situated at an elevation of over 4,000 feet, while Fort Smith, the old Government station on the edge of the Masai country, which is now abandoned, was built on a site 6,400 feet above sea level. The cool and bracing highlands of Kenya breed an active, sturdy native, who is a thrifty agriculturist and knows well how to utilize the rich, red soil of his country. The Akikuyu almost invariably build their villages on hill-tops and hill-sides where a good view of the surrounding country may be obtained and an approaching enemy seen from a distance. The terror inspired by raids of the Masai warriors in the past has implanted in them this act of caution to such an extent that it is now second nature, and a Kikuyu colony building their villages on a new site and in a locality perfectly free from the Masai, always select a high position on which to build, even though it may necessitate fetching the necessaries of life, such as water and firewood, from a long distance.

The Masai, on the other hand, build their manyata, or kraals, on some slightly elevated spot in the middle of a big plain where their herds of cattle can be easily pastured and for the most part visible from the kraal, since the young boys act as herdsmen and would be of small use in defending their charges against the raid of an enemy, armed as they are merely with a small bow and arrows.

The mountainous country in which the Akikuyu live has given them a slightly stooping carriage and bowed though muscular legs, which contrast disadvantageously with the perfectly moulded thigh and calf of the Masai. The fruitfulness of their fields have made them almost exclusively vegetarians and deprived them largely of that love of hunting which is so strong in the Dorrobo, and to a lesser degree in the Akamba, whose country is not nearly so fertile as Kenya.

The Kikuyu is pre-eminently a suspicious native. Having been in the past constantly on the look-out for the Masai he has become distrustful of others, and regards Europeans askance at the first introduction, although he may get to know 
afterwards that their friendship is sincere. From being distrustful he has become treacherous, possibly with the idea of being first in the field in case others have sinister designs against him. Having been generally worsted in his fights with the Masai, he has lost any feeling of over-weening confidence in his own prowess, a state of mind which is exclusively the property of the Masai, and is of opinion: like many other natives, that discretion is the better part of valour. Nevertheless he is a formidable adversary whose power of resistance in his own country it would be very unwise to underestimate.

The Akikuyu are hard-working, thrifty, and above all moral, and their place in the future of East Africa is already assured, if only from the fact that they are extraordinarily prolific and possess recuperative faculties as a tribe which make them quite inextinguishable. They cultivate their fields with unusual care for African natives, and greatly excel the Akamba and people of Teita in this respect. The soil of the highlands is a rich one, and as the rainfall of the two wet seasons, which cover a period of about eight months, amounts to between 40 and 50 inches, the crops are successful year in and year out and produce a surplus for sale and exchange. The home-grown diet of the Kikuyu is extremely varied as compared with that of other East African tribes. Maize, millet, and tree beans grow profusely in Kenya, as do also Kaffir corn and three kinds of ground beans, called by the Akikuyu mbosho, njari, and njoroko, and a choice of roots may be made among sweet potatoes, yams, and manioc, while bananas and sugar cane grow luxuriantly in all cultivated valleys, the former showing little or no inferiority to coast-grown fruit. The Akikuyu have but few cattle, and though every elder has a few sheep and goats, he seldom eats them, but uses them as a means of purchasing his wives or settling such claims as blood money and tribal fines.

\section{Physical Type.}

The Akikuyu, whose language is one of the great Bantu family of East Africa, south of the equator, are a well-built people of the negroid, prognathous, type of countenance with a smooth, dark reddish-brown skin.

In face they are markedly platyprosopic, their front being as a rule broad and flat, the cheek bones prominent, and the nose short and wide at the base, as in all negroid tribes. The lips are of medium thickness and slightly everted, and the mouth and chin broad. Between the upper incisors a slight aperture is filed, and both the lower incisors are sometimes knocked out. The eyes are almond-shaped and dark brown and are set somewhat obliquely under the eyebrows, the eyelashes being rather noticeably long. In body the Akikuyu are slenderly built, the arms being even slim and delicately moulded, and the fingers long and tapering. The legs, from the knee downward, are generally slightly bowed; the foot is small, well-built and has a well-marked instep. Viewed sidewise, the Kikuyu youth appears slightly inclined to steatopygy, but to nothing like the extent that is found among the Kaffirs. Owing to the women doing the majority of the manual work and becoming mothers at an early age, they soon lose the sprightliness of youth and in 
face and figure exhibit premature old age, while the men retain an upright form, springy step, and unimpaired courage right into middle age. Women retain a circular patch of hair round the back of their head and shave the hair over the forehead, above the ears, and around the neck. Elders either wear their hair short all over their head, or wear a small cap made of the entrails of a sheep. Circumcision is compulsory for both boys and girls after reaching the age of puberty, and is attended by dances and various ceremonies into which want of space will not allow me to go.

The various stages of the life of a Kikuyu are as follows:-A male child is called kahé until he has been circumcised, when he is known as a mwanake. This name he bears until he is recognized by the government and the elders themselves as of sufficient age to become an elder, when he becomes known as a mundu mzuri. A female child is called a karegu, and bears this name until she has been circumcised; afterwards she is known as a mwiretu, and does not change her status until after marriage, when she becomes a muhiki. A woman is known as a mutumia after the birth of her first child.

\section{Clothing.}

Prior to contact with civilization, the male Kikuyu wears a small garment of goat skin tied over his right shoulder and descending to just below the groin. This is called a kizii, and is generally changed for a blanket by the older men as soon as traders bring trade goods into the country. Some of the young men wear an oval piece of goat skin over the buttocks in imitation of the Masai warriors. This depends from the waist, hair outwards, is sometimes ornamented with beads, and is called an ndawa. Akikuyu youths, who have access to a bazaar, invariably wear a small piece of Americani (cloth sheeting) the size of the kizii, which is daubed with mutton fat and red clay, the edge being generally sewn with small white beads. The women wear three garments all made of goat or ox skin. First, a sort of cloak tied around the shoulders and hanging down below the waist. This is open in front and leaves the arms free for work. It is called a zetu, and is only worn by married women. A kind of skirt, called musuru, is worn round the loins and reaches nearly to the ground behind, and a small apron (mwengo), acting as the tongue of a shoe, is worn under the opening of the musuru in front. The clothes both of men and women are made by the men. They are sewn together with thread, made from the sinews of the back of a bullock, by means of an iron needle which is beaten out by skilled workmen from the iron ore found plentifully throughout Kikuyu. The needle has no eye, but is used to punch a hole through which the thread is passed. On the death of the wearer, the clothes are thrown away and never worn again. Big medicine men sometimes wear a leopard or lion's skin as a sign of their profession. The small skin caps worn by some elders are tied under the chin, cover the ears, and come down to the nape of the neck. They are generally fringed with small white beads. 


\section{Personal Ornaments.}

The young men allow their hair to grow to a length of 3 or 4 inches, when it assumes the appearance of small fillets, and is profusely greased with mutton fat and daubed with red clay which runs down over the neck and shoulders as far as the chest. The uniform length of the hair over the forehead presents a fringe-like aspect, but during running or any other action requiring unusual energy, the head assumes the appearance of a tumbled shock and considerably alters the looks of the wearer. Young dandies wear a tuft of feathers of the corvus semitorquatus, (called nderi by the Akikuyu), on the top of the head; these are cut short to the length of the hair and are smeared with fat and clay. Some of the elders shave the hair above the forehead and ears and around the neck, but this is not a frequent practice. Young unmarried women shave all the head with the exception of a very small patch on the apex, on which they sometimes fix a small portion of a bullock's shoulder bone. When a woman's child has been circumcised she may shave her whole head.

As a rule the Akikuyu do not wear beards or moustaches, but pluck out the hairs one by one with a pair of tweezers which, in common with the Akamba, they invariably carry at the end of a chain slung around their neck. A beard or moustache, if worn, is allowed to grow naturally and is not trimmed in any way. The ears of a full-grown man or married woman are heavily loaded with all sorts of ornaments, principally small hoops of red beads which are attached to the top of the ear and pull it right down over the orifice. The lobe of the ear is cut and stretched, and some heavy ornament, such as small hanging chains or heavy hoops of pink or red beads, depend therefrom. Frequently one or more strings of beads are threaded through these hoops and tied behind the neck like a necklace. A circular wooden disc is often inserted by both sexes in the lobe of the ear. Young men pierce four or five holes in the upper edges of the ears into which small sticks about an inch and half long, are inserted. These are taken out and replaced by circles of beads or iron rings later on in life. The young unmarried women wear beads in the upper parts of their ears and small sticks in the lobe, but a married woman, as soon as her first child has been circumcised, discards these sticks for hoops of beads. Many women imitate the Masai in wearing a huge coil of iron wire around their neck, and all girls and married women wear as many necklaces of beads as the generosity of their lovers or the wealth of their husbands will allow. Blue seems to be the favourite colour with the fair sex in this form of ornamentation.

Akikuyu young men wear brass and copper wire coiled around the arms between the shoulder and the elbow and around the wrists; around the legs between the knee and calf and around the ankle. These ornaments are not removed except in the case of a fracture of a limb. Iron rings are worn both on the first and second joints of the fingers; sometimes the upper part consists of a narrow, drawn out plate which reaches from finger nail to knuckle, and is roughly ornamented with small dents somewhat resembling the head of a thimble. Young men are allowed to wear ornaments as soon as they have been circumcised. 
Women as a rule do not affect heavy leg or arm ornaments, but generally wear a belt or double string of beads around the waist above the musuru. This belt is often composed of skin closely covered with different coloured beads worked in various patterns.

\section{Tribal Subdivisions.}

The following are the tribal sub-divisions of the Akikuyu :-

$\begin{array}{lllll}\text { Achera } & \text { Njirru } & \text { Athiageni } & \text { Ezuga } & \text { Aichakamuyu } \\ \text { Agachiko } & \text { Agathigia } & \text { Aithekahuno } & \text { Angari } & \text { Mbui }\end{array}$

\section{The Akamba.}

The Kitui District of Ukambani, in which I have collected the following notes, comprises all the country lying between the Athi and Tana Rivers, and is bounded on the east by the $39^{\circ}$ of longitude east and on the west by a straight line, drawn from the junction of the Thika River with the Tana, to the Donyo Sabuk Hill.

The Kamba tribe are also thickly settled over the whole of the Ulu District, which lies within the triangular loop of the Athi River, but are not found in any numbers south of the Uganda Railway in its route from Kibwezi to the Athi River Station. The country is on the whole dry, and, in the north-west corner of the Ulu District, fairly healthy, but both Kitui and Ulu suffered terribly from the famine of 1898 and 1899, when fifty per cent. of the Akamba are estimated to have died, despite the efforts of many Government Famine Camps and the untiring work of missionaries, aided by subscriptions from a private source in the British Isles. During this time many Akamba migrated to the Kikuyu country, where they stayed until 1900, selling cattle, and leaving their children in payment of food, to be afterwards redeemed when better days came round. The Akamba, despite the fact that they possess considerable herds of cattle, sheep, and goats, are primarily agriculturists, and will not part with their treasured herds except when driven to desperation by hunger. Many of them died of starvation, leaving their livestock to their children, sooner than kill what would have saved their lives.

The District of Kitui, though dry and fairly high lying, is unhealthy right through its length and breadth, and even the Akamba themselves suffer considerably from malaria. The Swahili and Masai say that it is the fever-laden east wind which brings malaria to Kitui, but doctors point to the presence of the Anopheles mosquito in all the small pools in Ukambani, and to them is probably traceable the prevalence of this form of illness throughout Kitui. The rich, red soil needs but sufficient rains to smile with abundant harvest, but it must be confessed that the natives do not back up the fertility of their country by good cultivation, their superficial scratching of the soil being, as in the case of many other African tribes, too often a contributory cause of partial and even total failure of their crops. I have grown a splendid crop of maize in my own garden on more than one occasion, when a partial failure of this cereal among the natives was general throughout Kitui. The Akamba scatter their villages broadcast over the country side, the Pax Britannica of the last six years having taught them that they have no longer 
anything to fear from the formerly dreaded Masai, on account of whose raids they used, in the old days, to conceal their huts in the bush in so cunning a manner that it took considerable practice to find out these clever hiding places. In the same way the thorn fence which formerly surrounded their villages, to which entrance was effected through a narrow tunnel of tree trunks, has been almost invariably discarded throughout Ukambani. The Kamba native hut is built in a circle of about 8 feet diameter, of slender sticks stuck into the ground, the whole reaching a point at the apex through which runs a centre pole of stout wood. The outside is loosely thatched and affords ingress through a small door about $2 \frac{1}{2}$ feet high.

Ukambani, or the country of the Akamba, attains in no part the altitude of the Kikuyu highlands, plains and low plateaux alternating with small hill ranges and deeply cut ravines. The Akamba, like the Akikuyu, avoid the plains, and build their villages along the shallow valleys and far-reaching spurs which run down from the hill ranges. 'The Akamba are not exclusively vegetarians. Although they seldom kill meat for ordinary purposes, they readily devour the flesh of cattle or goats.which have died a natural death, and in time of famine and during the dry season make up large hunting parties, when many hippopotami and not a few elephants fall under their spears and poisoned arrows. At these times their food is meat only. During the famine of 1898 and 1899 a few cases of cannibalism occurred in the Kitui and Ulu Districts.

The Akamba are not naturally suspicious and distrustful of strangers like the Akikuyu, neither do they in any way approach the latter in treachery.

In the old days when the Masai raided the whole of Ukambani, the Akamba frequently stood up to the bullying warriors to such good effect that the latter were often beaten off, and what loot they had already driven off taken away from them. Raiding among themselves has always been, and still is, a favourite occupation of the Akamba, and the Ulu chief, Mwatu, who is now a very old man, had a reputation as leader of war parties, ten years ago, second to no other chief in the Protectorate, while he is credited with having worsted the Masai in at least one encounter. Fighting is carried on almost exclusively with bows and arrows, which are smeared with a very deadly poison obtained from the bark of a tree, the name of which they will not divulge to Europeans. Spears are not much used, in which respect the Akamba differ from Kikuyu modes of warfare wherein the short, leaf-shaped thrusting spear plays an important and effective part.

The chief fault in the character of the Akambi is their incorrigible idleness and proneness to drunkenness after reaching the later years of manhood. As among nearly all African tribes, the women do all the work in the fields and are also hewers of wood and drawers of water, the men condescending to pound up and prepare the sugar cane and honey from which uki or native wine is made, and to inanufacture the iinga or bottle-shaped hives in which grain is stored after harrest. No attempt is made to cut the bush or improve the native paths running from village to village, and the Akamba fall a long way behind the Akikuyu in the neatness of their settlements and manufacture of their sleeping and grain huts. 
In morality the Akamba can certainly not be said to be on a level with the Akikuyu, nor do I consider that they are so prolific. Chastity is neither expected nor valued among women before marriage, and after all dances, in which young men and girls unite, promiscuous connection is indulged in and connived at by the parents of the latter. In the same way all married women have lovers, which is easily understandable when one bears in mind that nearly every man has two wives and the average number is three or four to each mutumia or elder. Rich men, with eight or nine or even more wives, are in the habit of lending a member of their harem to a friend in cases where no children are born as a fruit of the marriage. The offspring, if any, resulting from this are the property of the husband and are looked on as his children. Although it sometimes happens that in the case of unmarried girls pregnancy results from their intercourse with their lovers, this condition of the girl is no bar to her marriage with another man, but rather a recommendation, since he is sure of at least one child from her. If she wishes to marry her lover, however, she may do so and he must pay for her by instalments as soon as he is able. The usual dowry among the Akamba is from three to five head of cattle which is paid to the father, and in the case of the woman running away from her husband has to be returned to him again.

The Akamba do not cultivate their miunda or fields with the thoroughness or neat methods of the Akikuyu. They merely scratch the soil with pointed sticks after it has once been broken up with long sharpened poles. The soil of Ukamba is rich, but as a rule the rainfall is about 10 inches less than that of the Kikuyu highlands. Drought is common and deep cultivation alone will help the soil to retain moisture, as has been demonstrated by all Europeans who have grown garden produce in Ukambani. Maize, millet, nnveli and tree beans form the staple grain crops and are the principal food of the Akamba, while bananas and sugar cane grow in swampy valleys and on each side of the numerous ravines running down from hilltops. A kind of native vegetable marrow, called malengi, is sown and gathered once a year, being boiled and eaten in a rawish state. The kiteta, or calabash gourd, is allowed to grow ripe, when the inside is scraped out and the outside forms an excellent water-bottle, and if cut vertically two calabashes. Some elders have big herds of cattle, sheep, and goats which are used entirely for the purchase of wives, for the payment of blood money, and for redeeming from the Akikuyu any female relative who may have been left among them as hostage in time of famine.

\section{Physical Type.}

The Akamba, whose language, like that of the Akikuyu which it closely resembles, is of the Bantu family, are a fairly well-built race of negroids whose brown skin is a shade darker than that of Akikuyu. The woolly brown hair grows in little close tufts all over the head, but is only observable in this state among young boys, as the head is shaved by youths (after circumcision) with the exception of a small tuft where the whorl of hair occurs at the back of the head. All married men and elders shave the whole of the head, and so do young 
unmarried girls from time to time, probably every six months, but they do not keep the head close shaved as is the case with married women. The various stages of a Mukamba's life are as follows:-A male child is called a kivitzi at birth and retains this title until he is about ten years old, when he becomes a mwitzi, or youth. After marriage the Mukamba is known as a mwanake, and when he finds himself in a position to give a feast, and present the principal members among the elders invited with a goat, he is received among the elect and is known as a mutumia until the day of his death. He carries a long staff with a forked top, called an ndata, as his signal of elderhood. A girl is called a kaletu until she is old enough to think of a lover, when. she becomes a mweta or marriageable young woman, which appellation she retains until she is married and has borne a child, when she is usually alluded to as a kiveti. The term mundu $m u k a$ is used of speaking of a woman generally as opposed to a man. In face, the Akamba follow the platyprosopic type found all through the Bantu tribes. Their foreheads are not as a rule as broad as those of the Akikuyu, the cheek-bones are more inconspicuous, but the negroid nose is alike in both tribes. The whole face is more inclined to the short oval and less squarely moulded than that of the Mukikuyu, the lips are equally thick as those of the latter, but they do not strike one as being so conspicuously everted, even if there is a greater tendency for the lower lip to hang down, giving the owner a markedly sensual appearance. The eyes are dark brown and small, often presenting themselves to the beholder as mere slits, set horizontally under the eyebrows, and showing only a thin piece of the sclerotic at each end of the axis. The front teeth of the Ulu and Kitui Akamba are filed into a sharp point which causes them to decay rapidly before middle age, owing to the removal of the enamel. I cannot find any reason for supposing that this custom is a relic of cannibalism, although $I$ have heard it stated as such by African travellers. On account of this mutilation of the teeth the Akamba are unable to pronounce the letter $R$, for which they always substitute $L$. Among the Akamba living in the north-west part of the Kitui district the two upper incisors only are either partially filed where they join, or else are entirely knocked out. In every case in which I have asked for the reason of the mutilations I have been informed that it was done by way of ornament. Circumcision is universally practised among the Akamba, both on boys and girls, at the time of reaching puberty. The Akamba are as a rule of medium height, rather well knit above the waist, but generally, though not always, falling off below, and having slim, long legs with very little calf. As a rule they are not so bow-legged as the Akikuyu, their country being a flatter one. The arms are long proportionately with the legs, the fingers thin and slim. Here again, however, many exceptions present themselves, possibly owing to an admixture with another and shorter race. I have seen natives with short fleshy arms, thick spatulated fingers and distinctly muscular calves. I have seldom seen what could be called a good-looking Mukamba man, the face acquiring that heavy dull look after manhood which is so common among a polygamous and intemperate people; and although many of the women have 
pleasing faces during their girlhood, the advent of children and hard work in the fields soon robs women both of their natural form, especially in the abdominal region, and of any brightness or intelligence of face they may have previously possessed.

\section{Clothing.}

Skins formed the universal garments of both sexes until the arrival of Arab and Swahali traders, but the Akamba have been quicker to adopt the wearing of blankets and sheetings than either the Akikuyu or the Masai. Young men now invariably wear a small loin cloth of coloured cotton, and every elder wraps either a blanket or a long piece of white sheeting around the shoulders, the whole reaching to the ankles and the ends being crossed over the right shoulder. Young unmarried girls wear only two garments, an apron of cotton cloth about 6 inches deep and 14 inches long, and a small flap of the same length and slightly deeper worn over the nates. Both these are called kitemu. These are secured around the waist by a belt generally worked in beads. A small skin (oa) worn over the shoulders by the older women, resembles the zetu of the Akikuyu, a married woman invariably wearing a larger kitemu both behind and before than an unmarried girl. Children, until they are of an age to walk, are carried in a ngoi or leather sling on the back, the legs clasped around the mother's loins; little boys generally go naked until they are five or six yeurs old, but little girls always wear a tiny apron as soon as they can walk. The Akamba youths are very fond of wearing bright red fez caps which they buy in the bazaars, and, in common with most natives of East Africa, prefer the colour vermilion to either blue or white. Somalis and Swahilis on the east coast, and Hausas on the west, are the only tribes I have met which recognize how becoming white garments look against their rich brown or black skins.

\section{Personal Ornaments.}

The Mukamba youth, when he goes to a dance or is courting, wears a coil or two of mukunzu, or fine brass wire, bound around his forehead and the nape of the neck. A little white disc (about the size of a dollar) of snail shell is often bound to the unshaved tuft at the back of his head, and a fierce look given the face by rubbing mulitutu (or blue stone) or sirrga (red dye) around his eyes. Around the neck is worn the munyu, a finely linked copper chain, and several coils of white beads fall over the chest. The red and blue loin cloth is generally bound around the waist with several coils of mukunzu and both arms and legs, the former above the biceps and wrists, the latter around the calves, are decorated with several coils of heavy brass wire. A single garter of calf skin often decorates the knee on ordinary occasions. An elaborately wire bound knobkerry (nzoma) is only found in the equipment of very few dandies. The elders as a rule affect very few ornaments. Elulya, or iron ear ornaments, are generally worn, and on the fingers may be noticed two or three metal rings (ngomi). From the neck invariably depend kiangi (snuff flask) and ngula (tweezers) with which every single hair is carefully 
removed from the cheeks and chin. A single muthanga, or brass anklet, generally completes the ornaments of an elder.

Young girls wear at dances as many strings of blue and white beads around their necks as they can conveniently carry. Around the wrists and ankles are closely twisted long strings of the smallest white beads, which give the wearer the appearance of wearing white muffatees and spats. These are also occasionally worn by young men. The apron is often elaborately covered with cowries or white beads, and the belt thickly studded with similar ornaments of a like colour. Women wear a few blue beads around their neck and waist, but after the birth of the first child a inother usually begins to discard most of her elaborate ornaments which are simply adopted in courting days to attract lovers. In the Mumoni district of Kitui alone have I seen unmarried girls wear a thin leather cape (nguthi) so thickly sewn over with cowries (nguutu) that none of the underlying skin was visible. This garment reached down half way between the shoulder and elbow, was fastened in front, and was only donned by the wearers at dances.

\section{Tribal Sub-Divisions (Mumoni).}

$\begin{array}{lllll}\text { Mbanzi } & \text { Nguki } & \text { Kanyaa } & \text { Mula } & \text { Mbua } \\ \text { Matongoi } & \text { Muli } & \text { Kiluti } & \text { Nzau } & \text { Kathengi } \\ \text { Mwanziu } & \text { Nzuni } & \text { Katwui } & \text { Thiaka } & \end{array}$

In a subsequent paper I hope to give a short sketch of some of the more remarkable of the customs in practice among the Akikuyu and Akamba of Kenya and Kitui. I have subjoined herewith a short list of about three hundred Kikuyu and Kamba words showing how closely the two languages are allied, and append side by side the Swahili and Teita equivalent where affinity makes comparison interesting.

\begin{tabular}{|c|c|c|c|c|c|c|}
\hline ENGLish. & KIKUYU. & KAM & & Swahilt. & & Teita. \\
\hline 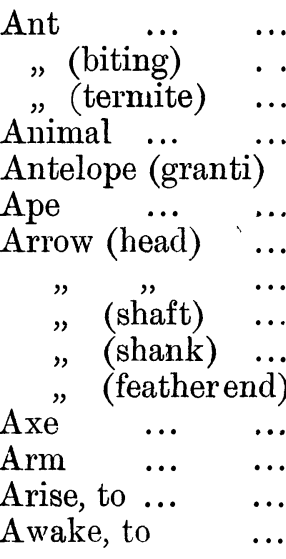 & \begin{tabular}{lr}
\multicolumn{2}{|l}{ ndutu (jigger } \\
thiraku &.. \\
muthwa &.. \\
nyamo &. \\
nguru &.. \\
nugu... &. \\
mungwi &. \\
\multicolumn{1}{|c}{..} & \\
kiano... &.. \\
ururu &.. \\
mbako &.. \\
ithanda &.. \\
woko ... &.. \\
ukirra &.. \\
kirria &..
\end{tabular} & $\begin{array}{l}\text { nguku } \\
\text { thilaku } \\
\text { mthuthu } \\
\text { nyamu } \\
\text { ngulu } \\
\text { nguli... } \\
\text { muzyi } \\
\quad \ldots \\
\text { chano } \\
\text { uthunzi } \\
\text { mbako } \\
\text { ithoka } \\
\text { kwoko } \\
\text { kila .... } \\
\text { am'ka }\end{array}$ & $\begin{array}{c}\cdots \\
\ldots \\
\ldots \\
\cdots \\
\cdots \\
\cdots \\
\cdots\end{array}$ & $\begin{array}{r}\text { chungu } \\
\text { siafu... } \\
\text { mchwa } \\
\text { nyama } \\
\text { swarce } \\
\text { nyani } \\
\text { mshale } \\
\quad \ldots \\
\ldots \\
\ldots \\
\quad \ldots \\
\text { shoka... } \\
\text { mkono } \\
\text { am'ka }\end{array}$ & $\begin{array}{c}\ldots \\
\ldots \\
\ldots \\
\ldots \\
\ldots \\
\ldots \\
\ldots\end{array}$ & $\begin{array}{l}\text { siafu. }{ }^{\circ} \\
\text { mzagu. } \\
\text { nyama. } \\
\text { sariga. } \\
\text { sabao, mbogo. } \\
\text { kiria (iron). } \\
\text { ivano(wooden). } \\
\text { mbugi. } \\
\text { uchungu. } \\
\text { wä̈. } \\
\text { izoka. } \\
\text { mkono. } \\
\text { uka. } \\
\text { vuka. }\end{array}$ \\
\hline
\end{tabular}




\begin{tabular}{|c|c|c|c|c|c|c|c|c|c|}
\hline \multicolumn{3}{|c|}{ English. } & \multicolumn{2}{|l|}{ KIKUYU. } & \multicolumn{2}{|l|}{ КАмва. } & \multicolumn{2}{|l|}{ Swahili. } & Teita. \\
\hline Ask, to & & .. & uria ... & .. & kulya & .. & uliza ... & & $\cdots$ \\
\hline Appear, to & & $\ldots$ & onwa... & $\ldots$ & oneka & .. & onekana & ... & $\ldots$ \\
\hline Alive & & $\cdots$ & hwari & $\ldots$ & -thaiyu & .. & hayi ... & $\begin{array}{l}\cdots \\
\cdots\end{array}$ & $\cdots$ \\
\hline Alone & $\ldots$ & $\ldots$ & -ike $\ldots$ & $\ldots$ & $-e k a \ldots$ & .. & (peke) yake & $\ldots$ & -ere. \\
\hline Above & $\ldots$ & .. & igurru & $\ldots$ & yulu ... & .. & juu ... & ... & juu. \\
\hline $\mathrm{Bag}$ & $\ldots$ & ... & kiondo & .. & chondo & .. & & & kidasi, kiłuchu. \\
\hline Beard & $\ldots$ & $\ldots$ & kideru & ... & kingethwa & .. & ndevu & .. & zombi. \\
\hline Bee & $\ldots$ & ... & njuki... & ... & nzuki & & nyuki & .. & choki. \\
\hline Blood & $\ldots$ & .. & nthakhame & ... & nthakhame & . & damu & .. & paga. \\
\hline Back & ... & $\ldots$ & mgongo & $\ldots$ & mwongo & .. & mgongo & ... & mgongo. \\
\hline Body & $\ldots$ & $\ldots$ & mwiri & ... & mwii... & .. & mwili & ... & mumbi. \\
\hline Bone & $\ldots$ & $\ldots$ & hindi... & ... & nindi & $\ldots$ & $\ldots$ & & indi. \\
\hline Bow & $\ldots$ & .. & $u t a \ldots$ & ... & $u t \alpha \ldots$ & $\ldots$ & utc $\quad \ldots$ & .. & ndance. \\
\hline Brains & ... & $\ldots$ & tombo... & .. & bwongo & .. & bongo... & ... & uongo. \\
\hline Banana . & $\cdots$ & ... & marigo & .. & maiyu & $\cdots$ & $\ldots$ & & irugne. \\
\hline Bowels . & $\cdots$ & $\ldots$ & $n d a \alpha \ldots$ & ... & $\operatorname{maa} \ldots$ & $\cdots$ & $\cdots$ & & kifu. \\
\hline Bamboo . & $\cdots$ & $\cdots$ & murangi & ... & mangi & . & mwanzi & .. & murangi. \\
\hline Bull . & $\cdots$ & $\ldots$ & nzau (calf) & $\ldots$ & nzau ... & $\cdot \cdot$ & $n z a u^{1}$ & .. & njau. \\
\hline Bullock . & $\ldots$ & $\ldots$ & ndewa & $\ldots$ & ndewa & $\cdots$ & & & mbiria. \\
\hline Buffalo . & ... & $\ldots$ & mbogo & $\ldots$ & $m b o \quad \ldots$ & $\cdots$ & $m b o g o^{1}$ & .. & mbogo. \\
\hline Buttocks . & ... & $\ldots$ & matina & $\ldots$ & matako & $\cdots$ & matako & .. & ishimba. \\
\hline ig, to . & ... & $\ldots$ & rehi ... & .. & eti $\quad \ldots$ & $\cdots$ & leta ... & ... & leta. \\
\hline Build, to . & $\cdots$ & $\ldots$ & $a k a \quad \ldots$ & $\ldots$ & $a k a \quad \ldots$ & $\cdots$ & $a k a \quad \ldots$ & $\ldots$ & $a g \alpha$, \\
\hline , to & $\ldots$ & $\ldots$ & inama & $\ldots$ & kunama & & inama & $\ldots$ & inama. \\
\hline Before & to & $\ldots$ & mberi... & $\cdots$ & mbee ... & ... & mbele... & $\ldots$ & mbele. \\
\hline Child ${ }^{\text {on, }}$ & $\ldots$ & $\begin{array}{l}\cdots \\
.\end{array}$ & kana... & $\ldots$ & mwana & .. & mwana & $\ldots$ & $\begin{array}{l}\text { kiria. } \\
\text { mivana. }\end{array}$ \\
\hline Caravan . & $\ldots$ & .. & kiaro... & $\ldots$ & chalo ... & .. & msafara & 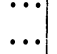 & charo. \\
\hline Crow & ... & $\cdots$ & igogo ... & $\ldots$ & ngunguu & $\ldots$ & kunguru & $\ldots$ & ngorusa. \\
\hline Cold & $\ldots$ & $\ldots$ & heho ... & ... & mbevo & .. & реро ... & $\ldots$ & mbeho. \\
\hline Clothes . & ... & $\ldots$ & nguo ... & ... & ngua ... & .. & nguo ... & $\ldots$ & ngıนo. \\
\hline Cow & ... & $\ldots$ & ngombe & $\ldots$ & ngombe & ... & ngombe & ... & ngombe. \\
\hline Crocodile. & $\ldots$ & $\ldots$ & kingangi & ... & lieingangi & $\ldots$ & ngwena & $\ldots$ & mamba. \\
\hline Come out, & , to & $\ldots$ & uma ... & $\ldots$ & uma ... & $\ldots$ & $\ldots$ & & fuma. \\
\hline Call, to . & ... & $\ldots$ & ita $\quad \ldots$ & $\ldots$ & eta $\ldots$ & $\ldots$ & ita $\quad \ldots$ & $\cdots$ & $i t a$. \\
\hline Carry & ... & $\ldots$ & $k u \alpha \ldots$ & $\ldots$ & kua ... & $\ldots$ & chuku & $\ldots$ & tuala. \\
\hline Cheat & .. & $\ldots$ & henya & $\ldots$ & kenga & $\ldots$ & danganya & $\ldots$ & kalia. \\
\hline Cover, to . & $\ldots$ & $\ldots$ & kunika & $\ldots$ & kunika & ... & funika & ... & finikila \\
\hline Climb, to & $\ldots$ & $\ldots$ & handa & $\ldots$ & ndanya & $\ldots$ & panda & .. & jok $\alpha$. \\
\hline Cry & ... & ... & $\operatorname{rir\alpha } \ldots$ & $\ldots$ & $i a$ & $\ldots$ & lia $\ldots$ & ... & lila. \\
\hline Check, to & $\ldots$ & $\ldots$ & giria... & $\ldots$ & dzyia.... & $\ldots$ & zuia ... & $\cdots$ & legea. \\
\hline Jure, to & $\ldots$ & $\ldots$ & honya & $\ldots$ & vonoch $\alpha$ & $\ldots$ & ponya & ... & okola. \\
\hline . & $\ldots$ & $\cdots$ & muthenya & $\cdots$ & muthenya & $\cdots$ & mehance & $\cdots$ & lavu. \\
\hline Door & $\ldots$ & $\cdots$ & maromo & $\ldots$ & mwomo & $\cdots$ & $\cdots$ & & mlango. \\
\hline Dog (wild & & .. & ngui ...: & & nzui $\ldots$. & $\cdots$ & $\cdots$ & & koshi. \\
\hline Drum & ... & .. & $\begin{array}{c}\text { kihembi } \\
\text { honey) }\end{array}$ & for & kithembi & $\ldots$ & ngoma & $\cdots$ & ngoma. \\
\hline Devil & $\cdots$ & $\cdots$ & ngoma & .. & $\operatorname{aimo} \ldots$ & $\cdots$ & & & mkinya, mbeho \\
\hline Die, to & ... & ... & $k u-k w \alpha$ & ... & $k u-k w a$ & ... & $k u-f a . .$. & & fwa. \\
\hline Do, to & $\ldots$ & $\cdots$ & eka $\ldots$ & $\ldots$ & $i k \alpha \quad \ldots$ & & weka (to plac & ce) & \\
\hline
\end{tabular}

1 Giriama dialect. 


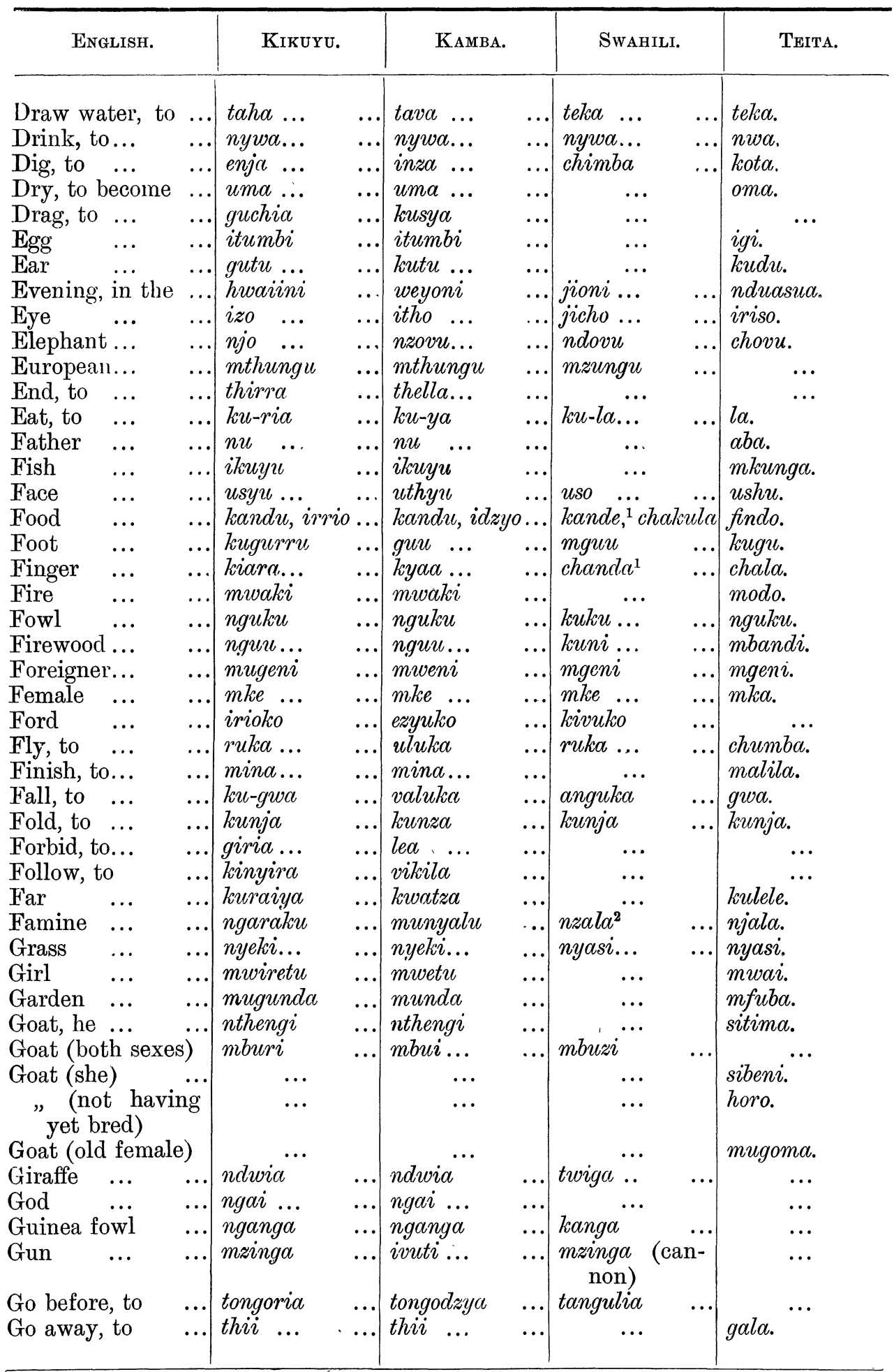




\begin{tabular}{|c|c|c|c|c|c|c|c|c|}
\hline \multicolumn{3}{|c|}{ English. } & KIKUYU. & \multicolumn{2}{|l|}{ KАMвA. } & \multicolumn{2}{|l|}{ SwaHILI. } & Teita. \\
\hline Grind, to & & & thea ... & thia ... & $\ldots$ & $\operatorname{saga} \ldots$ & & $\ldots$ \\
\hline Great & $\cdots$ & $\ldots$ & -nene... & - nene... & $\begin{array}{l}\cdots \\
\ldots\end{array}$ & -nene... & $\cdots$ & $\ldots$ \\
\hline Gratis & & $\ldots$ & $\operatorname{man} \alpha$ & $\operatorname{man} \alpha$ & $\ldots$ & $\ldots$ & & burre. \\
\hline Go bad, t & & $\ldots$ & buza ... & oa $\quad \ldots$ & $\ldots$ & $o z \alpha \quad \ldots$ & ... & $\ldots$ \\
\hline Hair & $\ldots$ & $\ldots$ & nzwiri & nzwii... & $\ldots$ & nyele... & .. & ndidia. \\
\hline Hand & $\ldots$ & $\ldots$ & $\ldots$ & $\ldots$ & & & & mkono. \\
\hline Hole & $\ldots$ & $\ldots$ & mwanya & itonni & .. & kipenyo & ... & kidanga. \\
\hline House & $\ldots$ & $\ldots$ & nyumb̆a & .. nyumba & ... & nyumba & $\ldots$ & nуumba. \\
\hline Head & $\ldots$ & $\ldots$ & mutwi & mutwi & $\ldots$ & kíchwa & ... & chongo. \\
\hline Herdsmar & & $\ldots$ & murithi & mwithi & .. & $\ldots$ & & mlisha. \\
\hline Harteb & ste & $\ldots$ & ngondi & ngondi & .. & kongoni & ... & ngwale. \\
\hline Hippopot & amus & $\ldots$ & nguu... & ngıьo ... & $\ldots$ & kiboko & ... & ngoluma, nguo. \\
\hline Honey & ... & $\ldots$ & $u k i \quad \ldots$ & . $u k i \quad \ldots$ & $\ldots$ & $\ldots$ & & vuki. \\
\hline Horn & $\ldots$ & $\ldots$ & ruhya & uvya ... & $\ldots$ & $\ldots$ & & luembi. \\
\hline Hunger & $\ldots$ & .. & ngaraku & nzad ... & $\ldots$ & njaа ... & $\ldots$ & njala. \\
\hline Hill & $\ldots$ & .. & kirima & kiima & $\ldots$ & kilima & $\ldots$ & kilima. \\
\hline Hut & $\ldots$ & $\ldots$ & kathuno & kathuno & $\ldots$ & $\ldots$ & & kigaro, chanda. \\
\hline Hyena & $\ldots$ & $\ldots$ & hiti ... & mbiti... & $\ldots$ & fisi $\ldots$ & $\ldots$ & mbisi. \\
\hline Hear, to & $\ldots$ & $\ldots$ & $i g w a \ldots$ & $i w \alpha \ldots$ & $\ldots$ & sikia ... & $\ldots$ & sikila. \\
\hline Hide, to & $\ldots$ & $\ldots$ & hitha... & vitha... & $\ldots$ & fich $\alpha \ldots$ & $\ldots$ & fisa. \\
\hline Harm, to & & $\ldots$ & ehia ... & thea ... & $\ldots$ & & & \\
\hline Hold, to & ... & $\ldots$ & $a t a \ldots$ & ata $\quad \ldots$ & $\ldots$ & kamata & ... & gwada. \\
\hline Hunt, to & $\ldots$ & .. & gwima & zyema & ... & winda & $\ldots$ & dega. \\
\hline Heavy & .. & ... & -rito ... & -wito... & $\ldots$ & -zito ... & $\ldots$ & $\ldots$ \\
\hline Here & $\ldots$ & .. & haha... & bac $\ldots$ & .. & hapa... & $\ldots$ & aha. \\
\hline & .. & .. & ninyi & nye $\ldots$ & $\ldots$ & $n i-\quad \ldots$ & $\ldots$ & mimi. \\
\hline nsect & $\ldots$ & . & kankyamu & kasamu & .. & $\ldots$ & & mdudu. \\
\hline Iron & $\ldots$ & $\ldots$ & $\begin{array}{l}\text { mulinga (iror } \\
\text { wire) }\end{array}$ & kiaa ... & ... & chuma & $\ldots$ & chuma. \\
\hline Interpret & & $\cdots$ & muthamaki. & mumanezyi & $\cdots$ & mkulimani & .. & $\cdots$ \\
\hline Ill & $\ldots$ & .. & morruaru & muvvau & $\ldots$ & $\cdots$ & & $\cdots$ \\
\hline Inside & $\ldots$ & $\ldots$ & nthini & nthini & ... & ndani & $\ldots$ & $\ldots$ \\
\hline Jigger & .. & $\ldots$ & ndutu & lulu ... & $\ldots$ & funza & $\ldots$ & $\ldots$ \\
\hline Jackal & $\ldots$ & $\ldots$ & mbwe... & mbewa & .. & mbweh $\alpha$ & $\ldots$ & .. \\
\hline Jealous & $\ldots$ & $\ldots$ & $\ldots$ & $\cdots$ & & $\ldots$ & & mwivu. \\
\hline Knee & $\ldots$ & $\ldots$ & iru ... & egu $\quad \ldots$ & $\cdots$ & $\ldots$ & & kitembero. \\
\hline Knife & & $\ldots$ & kahiyu & kavyu & .. & kisu ... & ... & $\ldots$ \\
\hline$" \quad(b i$ & & $\ldots$ & $\cdots$ & & & $\ldots$ & & lufu. \\
\hline " (sm & nall) & $\ldots$ & $\ldots$ & & & ... & & ndaga. \\
\hline $\begin{array}{l}\text { Knobkerr } \\
\text { Kill, to }\end{array}$ & & $\ldots$ & njoguma & nzoma & $\ldots$ & & & rungu. \\
\hline $\begin{array}{l}\text { Kill, to } \\
\text { Know, to }\end{array}$ & ... & $\ldots$ & hura... & $k u-\alpha a$ & ... & $k u-u \alpha$ & $\ldots$ & mbwaga. \\
\hline $\begin{array}{l}\text { Know, to } \\
\text { Lip }\end{array}$ & $\ldots$ & .. & menya & manya & $\cdots$ & $\operatorname{many} \alpha^{1}$ & $\cdots$ & mamya. \\
\hline $\begin{array}{l}\text { Lip } \\
\text { Lake }\end{array}$ & $\ldots$ & .. & kiromo & mwomo & $\ldots$ & mdomo & $\cdots$ & momo. \\
\hline $\begin{array}{l}\text { Lake } \\
\text { Leg }\end{array}$ & $\ldots$ & .. & iria ... & $i i \alpha$ & $\ldots$ & ziwa ... & $\ldots$ & $z i w a$ \\
\hline Leg & $\ldots$ & ... & kugursu & guu $\ldots$ & $\ldots$ & mguu... & $\ldots$ & kugu. \\
\hline $\begin{array}{l}\text { Leopard } \\
\text { Lizard }\end{array}$ & $\cdots$ & . & ngari... & $n g u \ldots$ & ... & chui ... & $\ldots$ & ingi. \\
\hline $\begin{array}{l}\text { Lizard } \\
\text { Lion }\end{array}$ & $\cdots$ & .. & tambazi & mwilo & $\cdots$ & mjusi & $\cdots$ & machoronyo. \\
\hline Lion & ... & .. & $\begin{array}{l}\text { malozi, mun } \\
\text { yambo }\end{array}$ & munyambo & .. & $\operatorname{simba}$ & ... & munyambo. \\
\hline
\end{tabular}

1 Giriama dialect. 


\begin{tabular}{|c|c|c|c|c|c|c|c|c|}
\hline & \multicolumn{2}{|l|}{ NGLISH. } & \multicolumn{2}{|l|}{ KIKUYU. } & \multicolumn{2}{|l|}{ KaMBA. } & Swahili. & Teita. \\
\hline
\end{tabular}

1 Used by boy to mother.

2 Used by girl to mother.

${ }^{3}$ Giriama dialect. 


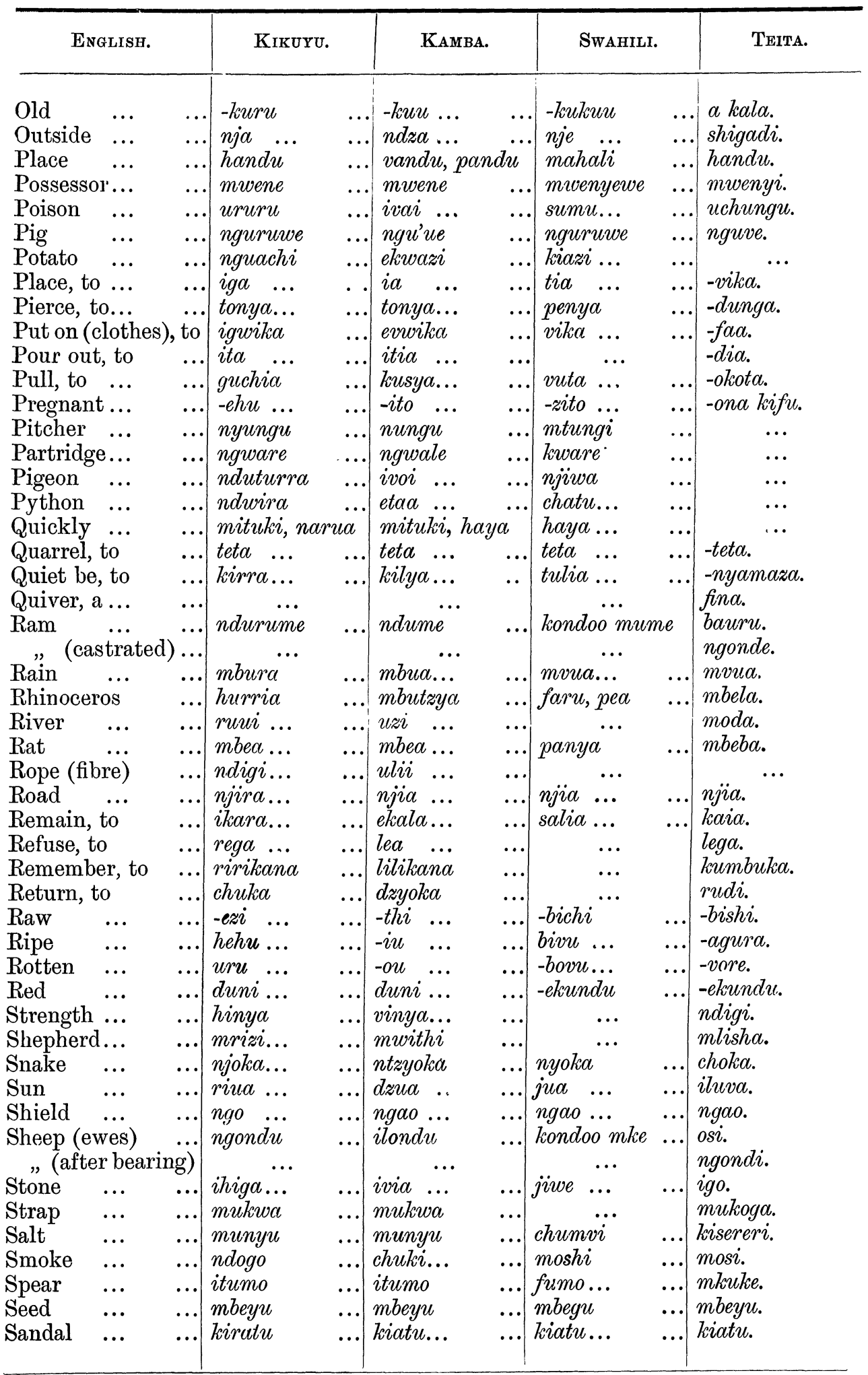




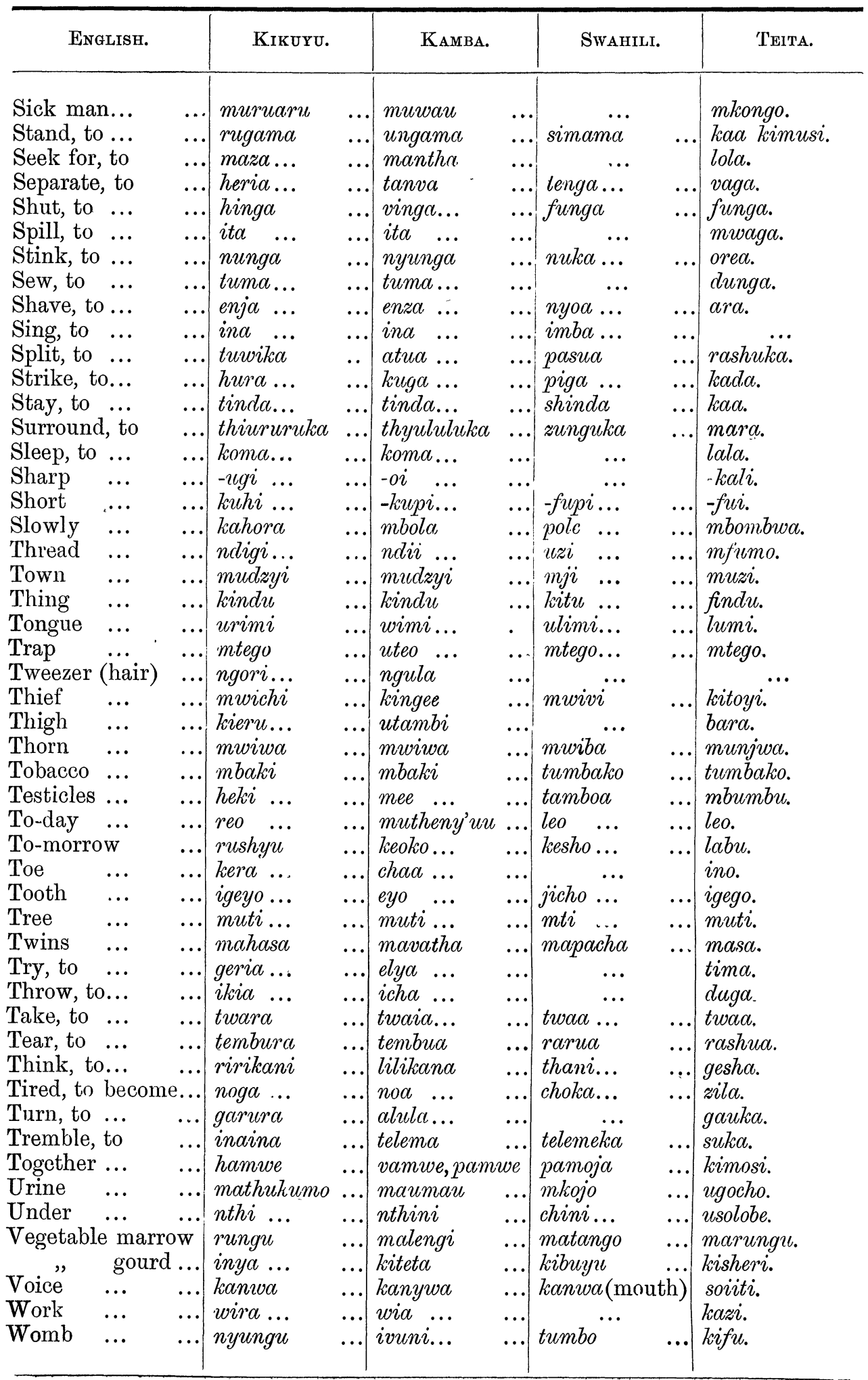




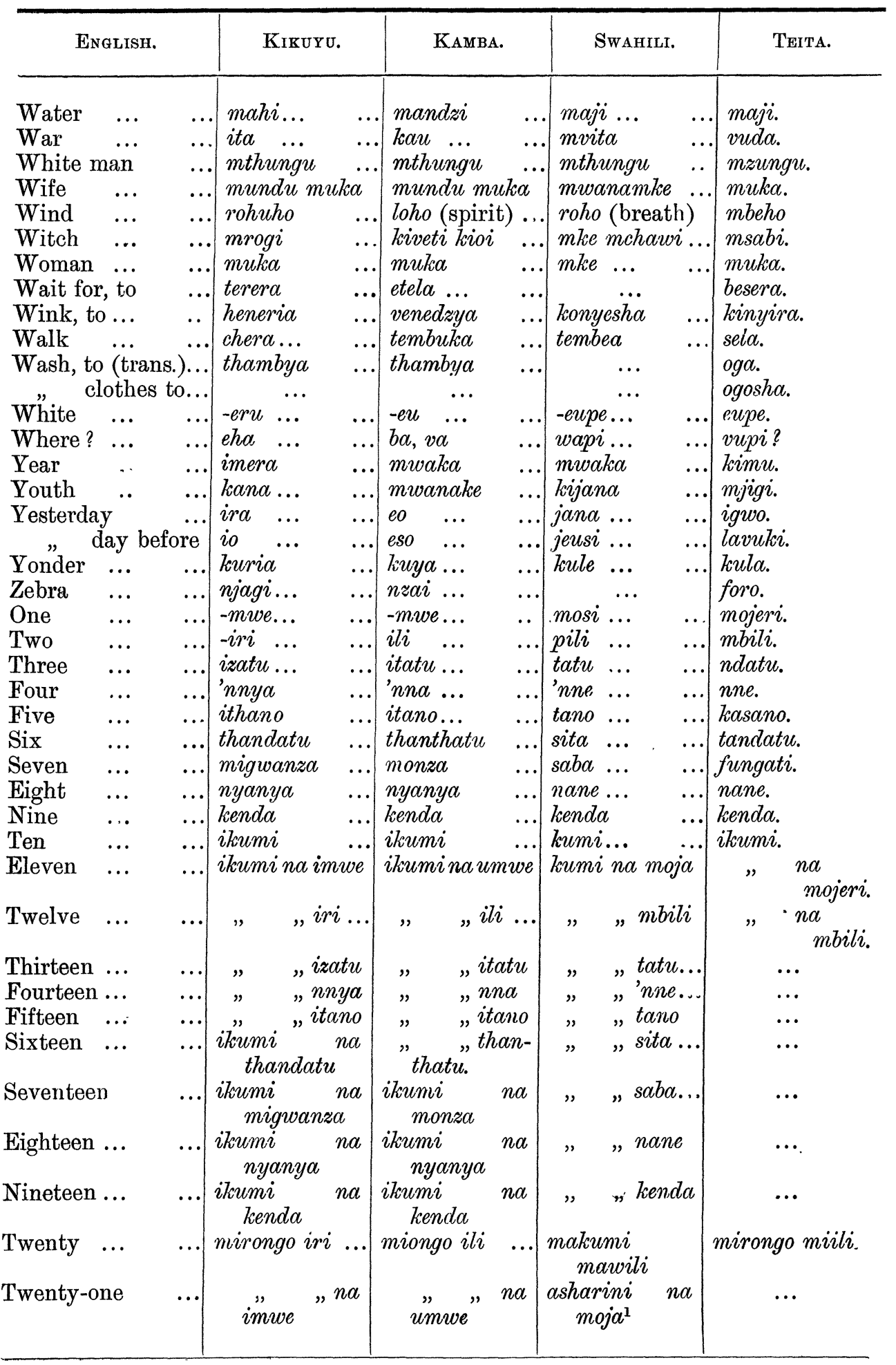

1 Arabic. 
148 H. R. TATE.-Notes on the Kikuyu and Kamba Tribes of British East Africa.

\begin{tabular}{|c|c|c|c|c|c|c|}
\hline \multicolumn{3}{|c|}{ English. } & KıKUYU. & $\mathrm{K}_{\triangle \mathrm{MBA}}$. & Swahili. & Teita. \\
\hline Thirty & $\cdots$ & $\cdots$ & mirongo izatu & miongo mitatu & $\begin{array}{l}\text { makumi } \\
\text { matatu }\end{array}$ & ${ }_{\text {mitatu. }}^{\text {mirongo }}$ \\
\hline Forty & $\cdots$ & $\ldots$ & "' 'nna & $" n n a \ldots$ & $\begin{array}{l}\text { makumi } \\
\text { manne }\end{array}$ & minne. \\
\hline Fifty & $\ldots$ & ... & $" \quad$ itano & $"$ itano... & $\begin{array}{l}\text { makumi } \\
\text { matano }\end{array}$ & " mitano. \\
\hline Sixty & $\ldots$ & $\ldots$ & $\begin{array}{l}\text { mirongo than- } \\
\text { datu }\end{array}$ & thatu ${ }^{\text {than- }}$ & makumi sita... & $\begin{array}{l}\text { mirongo } \\
\quad \text { mitano atu. }\end{array}$ \\
\hline Seventy & ... & ... & $\begin{array}{l}\text { mirongo mig- } \\
\text { wanza }\end{array}$ & miongo monza & $s a b a$ & $\begin{array}{l}\text { mirongo } \\
\text { mfungati. }\end{array}$ \\
\hline Eighty & $\ldots$ & $\cdots$ & $\begin{array}{l}\text { mirongo nyan- } \\
\text { ya }\end{array}$ & "nyanya & "manane & $\begin{array}{l}\text { mirongo } \\
\text { minane. }\end{array}$ \\
\hline $\begin{array}{l}\text { Ninety } \\
\text { Hundre }\end{array}$ & & & mirongo kenda & "kenda... & ,kenda... & mirongo kenda. \\
\hline Two hun & dred & & $\begin{array}{l}\operatorname{mgana} \\
\operatorname{magana} \text { meri }\end{array}$ & $\begin{array}{lll}\text { eana } & \ldots & \\
\text { eana } & i l i & \\
\end{array}$ & $\begin{array}{l}\text { mia }^{1} \ldots \\
\text { miteen }^{1}\end{array}$ & $\begin{array}{r}\text { igaona. } \\
\ldots\end{array}$ \\
\hline
\end{tabular}

${ }^{1}$ In Kikuyu the cardinal numbers are scarcely ever used beyond 100. Ngiri = "very many," represents an amount which cannot be counted. 
Journal of the Anthropological Institute, Vol. XXXIV, 1904, Plate II.
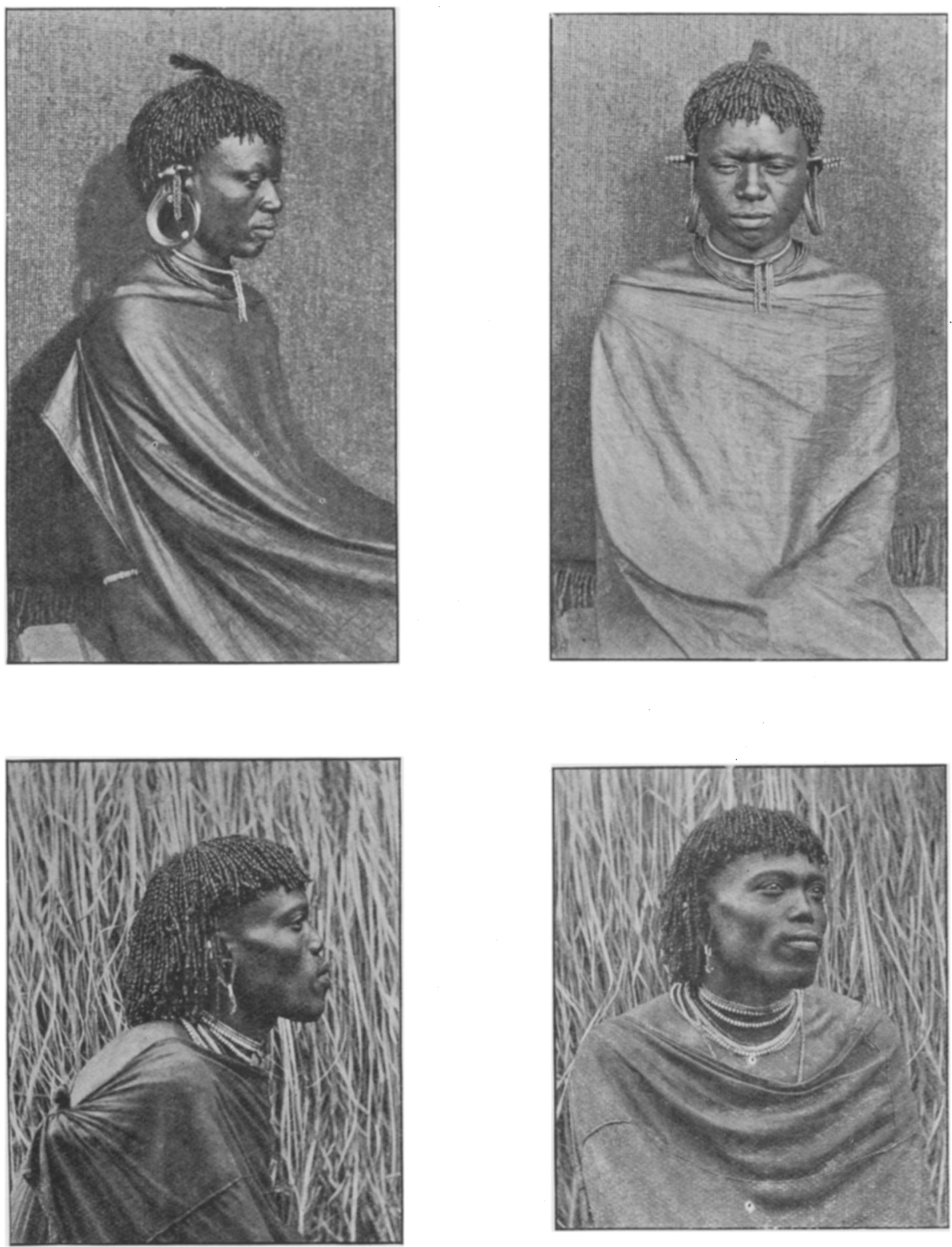

Photographs by W. Scorcsby Routledge, Bsq.

KIKUYU TYPES.

THE KIKUYU AND KAMBA TRIBES, BRITISH EAST AFRICA. 


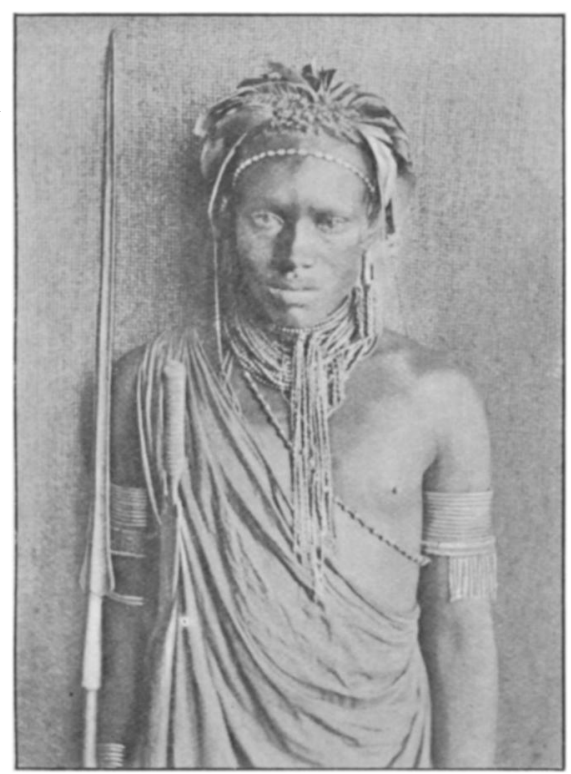

A DANDY.

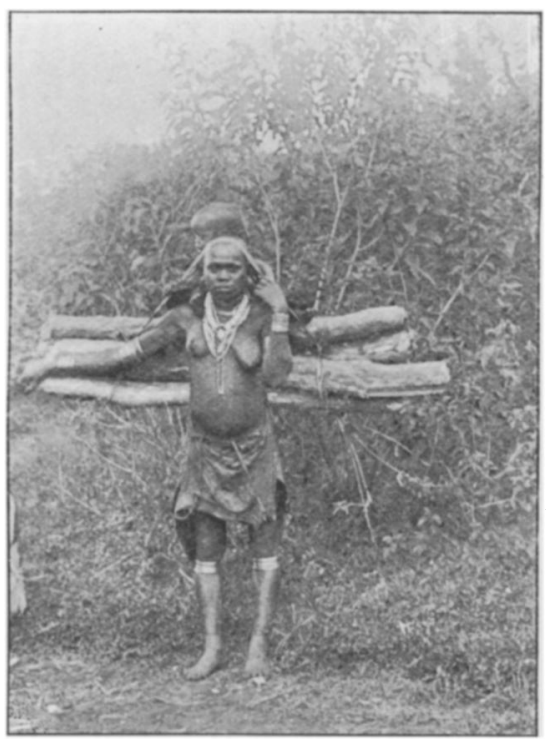

KIKUYU MATRON.

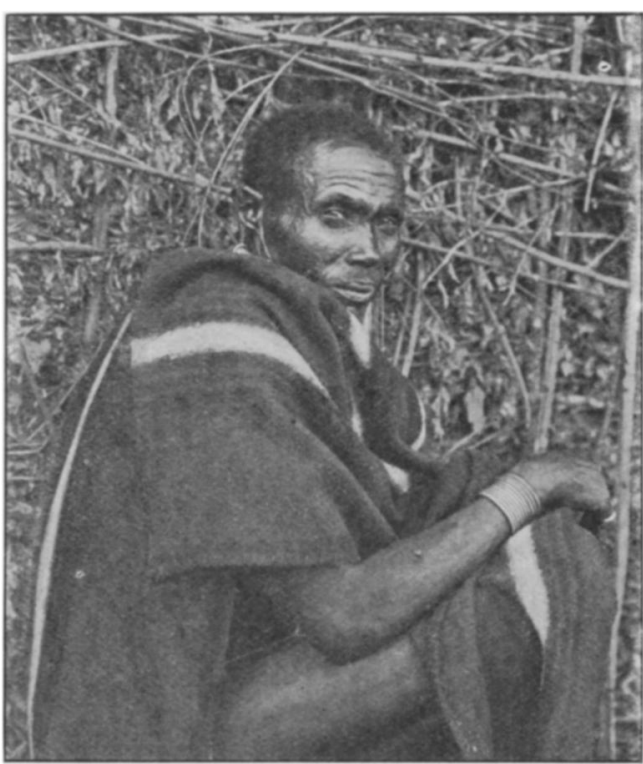

A "MUNDU MZURI."

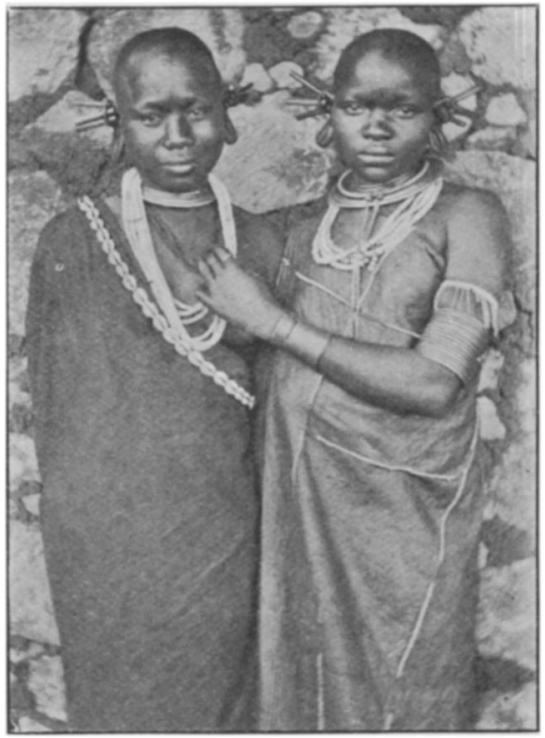

KIKUKU UNMARRIED GIRLS.

Photographs by W. Scoresby Routledge, Esq.

THE KIKUYU AND KAMBA TRIBES, BRITISH EAST AFRICA. 
Journal of the Anthropological Institute, Vol. XXXIV, 1904, Plate IV.

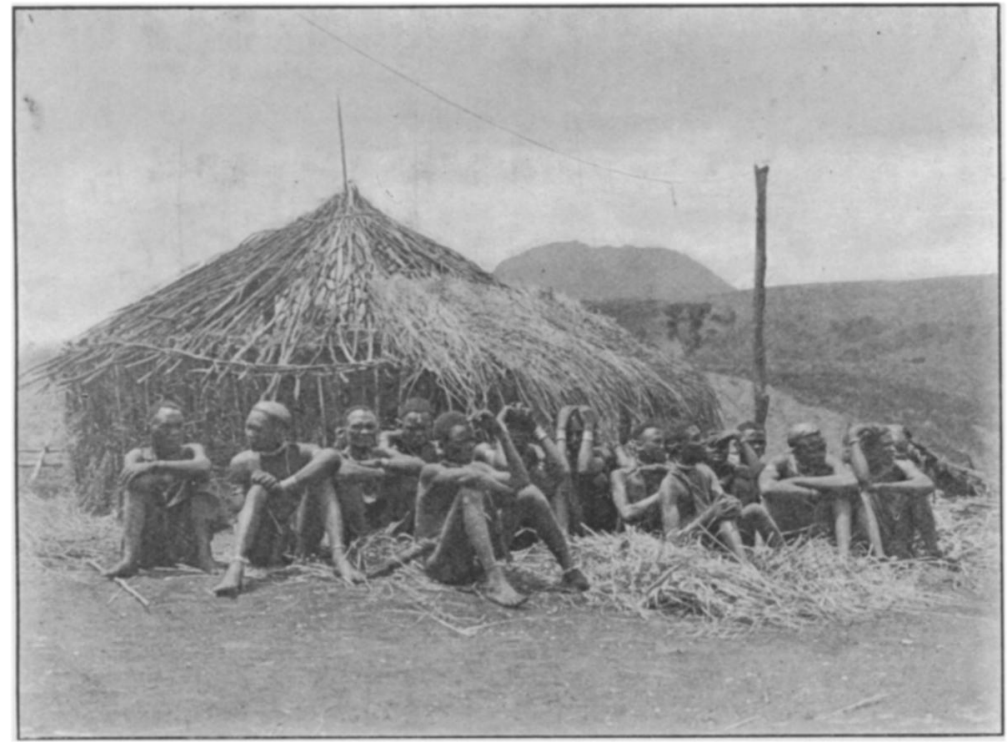

KIKUYU SKELETON HOT.

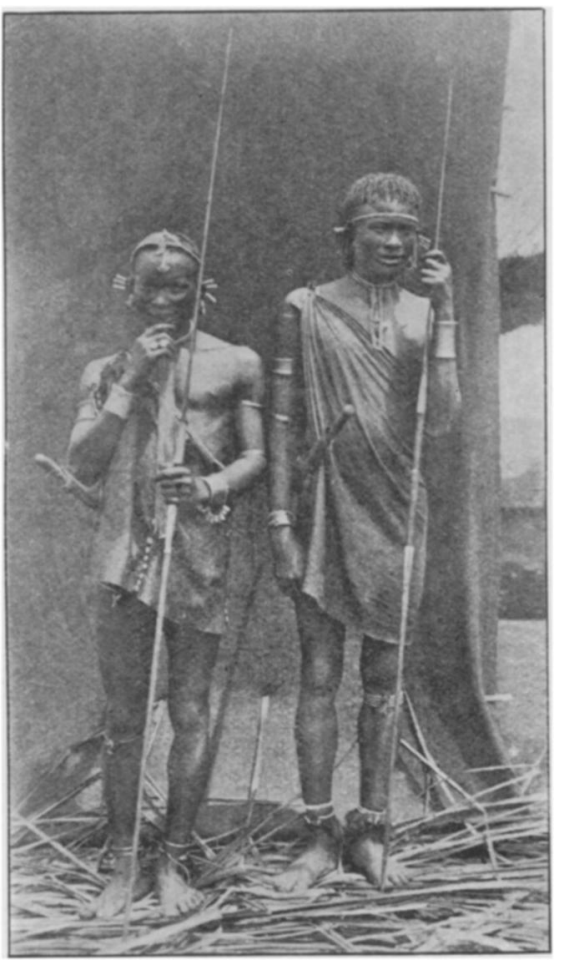

KIKUYU YOUTHS.

Photographs by $W$. Scoresby Routledge, Bsq.

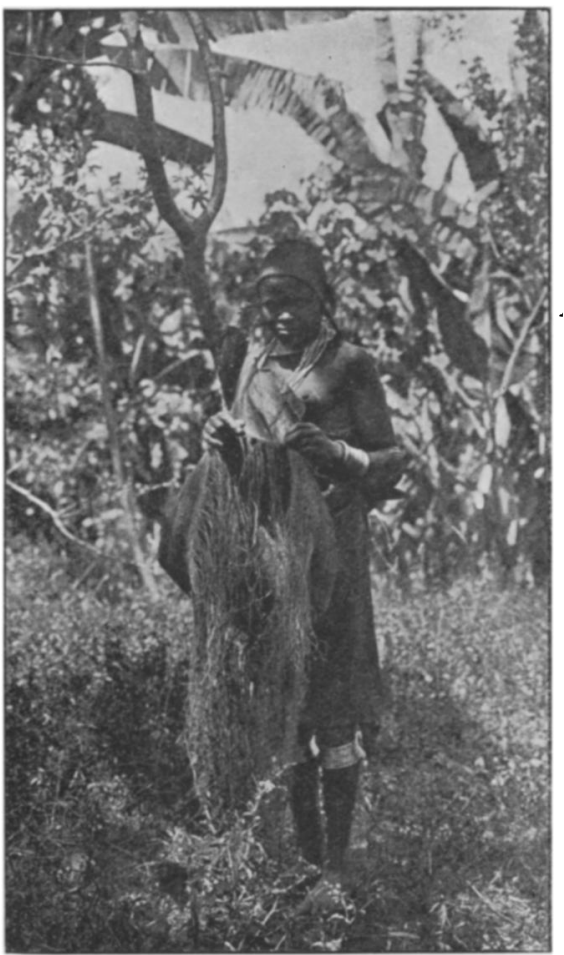

KIKUYU BAG MAKING.

THE KIKUYU AND KAMBA TRIBES, BRITISH FAST AFRICA. 
Journal of the Anthropological Institute, Vol. $X X X I V, 1904$, Plate $V$.

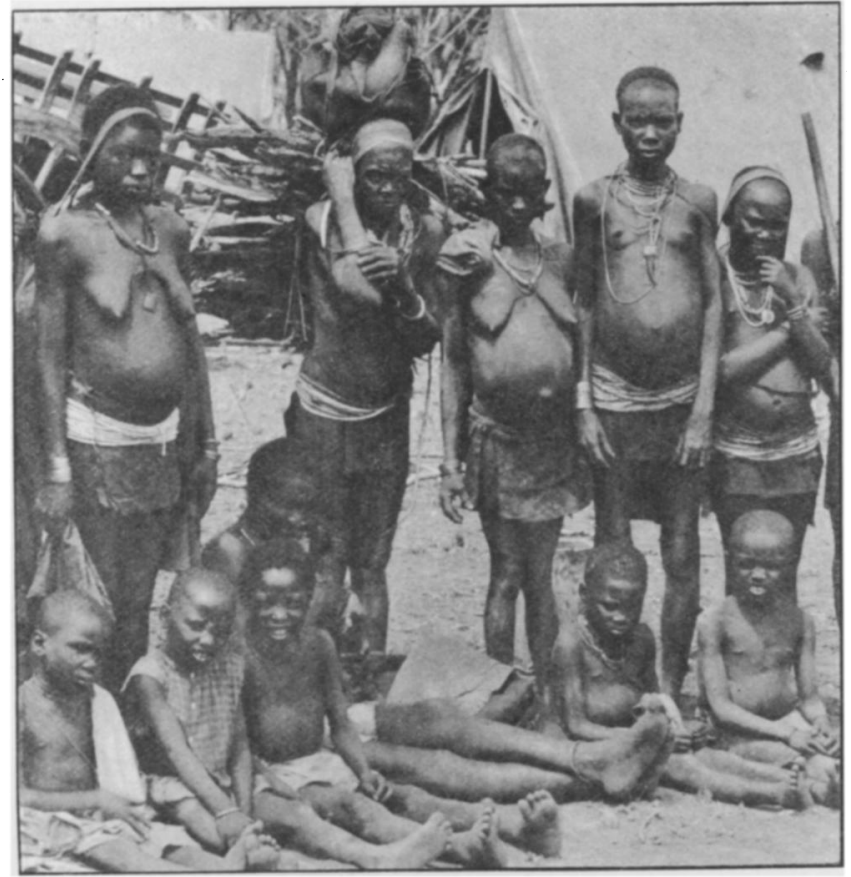

RAMBA WOMEN.

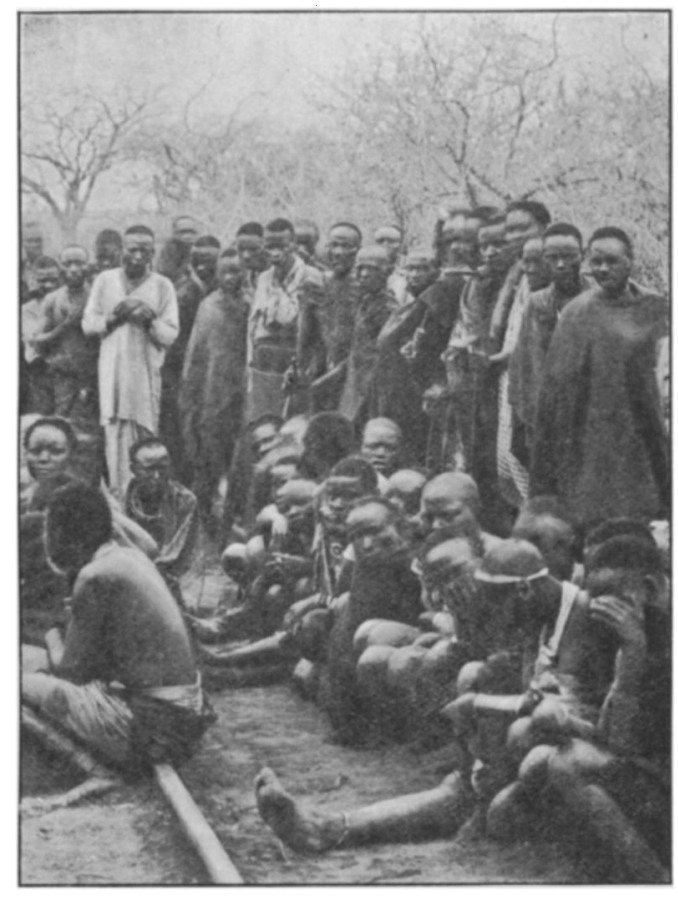

A KAMBa caravan.

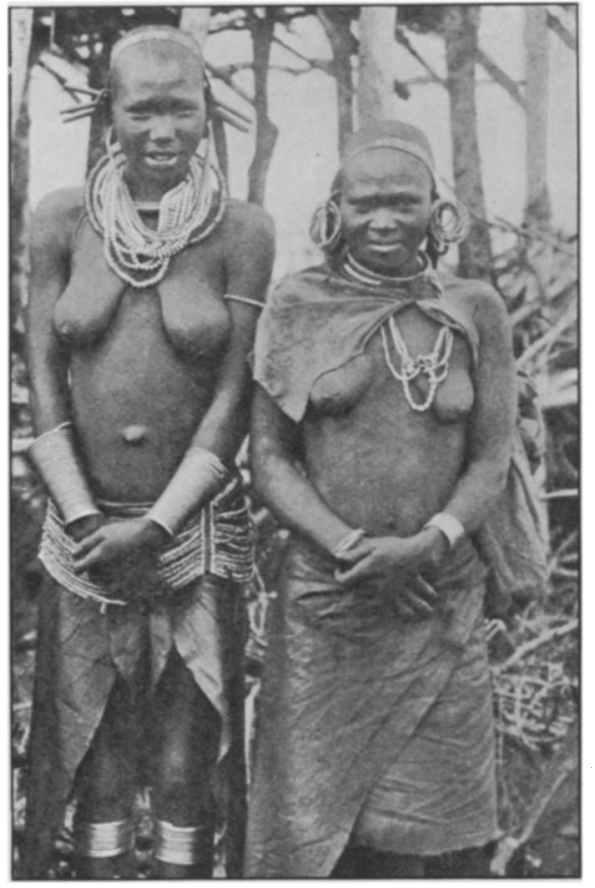

KIRUYU WOMEN.

THE KIKUYU AND KAMBA TRIBES: BRITISH EAST AFRICA. 